\title{
STUDI IN SILICO POTENSI SENYAWA ALLIIN BAWANG PUTIH (Allium sativum) SEBAGAI INHIBITOR DPP-4 PADA DIABETES MELLITUS
}

\section{(STUDY IN SILICO OF THE POTENCY OF GARLIC ALLIIN COMPLEX (Allium sativum) AS DPP-4 INHIBITOR ON DIABETES MELLITUS)}

\author{
MARTINA KURNIA ROHMAH ${ }^{\bullet}$ \\ ${ }^{1}$ STIKes Rumah Sakit Anwar Medika
}

\begin{abstract}
Abstrak: Diabetes mellitus (DM) merupakan penyakit gangguan metabolisme glukosa yang dicirikan dengan gangguan sekresi dan resistensi insulin. Jalur pengobatan DM baru pada sistem increatin dengan penghambatan terhadap DPP-4 telah dikembangkan dan terbukti efektif untuk meningkatkan sekresi insulin, menjaga integritas sel $\beta$-pankreas, memperlambat pengosongan lambung dan meningkatkan lipogenesis tanpa menyebabkan efek samping sistemik. Bawang putih (Allium sativum) diketahui memiliki aktivitas antidiabetes di antaranya meningkatkan sekresi insulin dan menurunkan level glukosa plasma, memiliki aktivitas insulinotropik dibandingkan dengan hypoglikemik. Namun demikian mekanisme molekuler dari aktivitas ini belum banyak diketahui. Penelitian ini bertujuan untuk mengetahui potensi senyawa Alliin pada bawang putih (Allium sativum) sebagai inhibitor DPP-4 secara in silico menggunakan metode docking server. Hasil penelitian ini menunjukkan bahwa, senyawa Alliin terbukti dapat berikatan kuat dengan DPP-4 dengan interaksi permukaan sebesar 120.032. Ikatan Alliin dan DPP-4 sangat stabil dibuktikan dengan energi ikatan bebas yang kecil $(-0.59 \mathrm{kcal} / \mathrm{mol})$. Alliin juga terbukti memiliki aktivitas penghambatan pada DPP-4 inhibitor dibuktikan nilai konstanta inhibisi (Ki) yaitu $792.92 \mathrm{mM}$. Hal ini didukung oleh adanya kesamaan struktur antara ikatan rangkap $\mathrm{O}(=\mathrm{O})$ dan $\mathrm{NH}_{2}$ antara alliin dengan saxagliptin. Penelitian ini membuktikan bahwa senyawa Alliin dapat berikatan dengan DPP-4 dan mampu memberikan efek penghambatan.
\end{abstract}

Kata Kunci: Diabetes mellitus, DPP-4, Inhibitor, in silico

\begin{abstract}
Diabetes mellitus (DM) is a glucose metabolic disorder that characterized with insulin secretion interference and resistance. Now days, the new treatment method for DM by increatin system and DPP-4 inhibition have been developing to increase insulin secretion, keep $\beta$-cell integrity, shorten the gastric emptying, and accelerate lypogenesis without the metabolic effect. Garlic (Allium sativum) has antidiabetic activity like increase insulin secretion, decrease the glucose plasma level, and insulinothropic. However, the molecular mechanism of this activity has not been fully elucidated. This research aims to investigate the potential of Alliin to inhibit DPP-4 activity by using in silico test. This study shown that Alliin have highly interaction and inhibitory activity in DPP-4. It was proven by high interaction surface (120.031), low free energy binding $(-0.59 \mathrm{kcal} / \mathrm{mol})$, and low inhibition constant value $(792.92 \mathrm{mM})$. It was indicated that we can use Alliin as alternative therapy in DM by DPP-4 inhibition activity.
\end{abstract}

Keyword: Diabetes mellitus, Inhibitor, DPP-4, in silico

\section{PENDAHULUAN}

Diabetes mellitus (DM) merupakan penyakit dengan jumlah kasus dan kematian yang terus meningkat. Pada tahun 2014, jumlah penderita DM mencapai 422 juta jiwa, dengan angka kematian mencapai 1.5 juta jiwa, serta menempati urutan ke-7 penyebab kematian di dunia. Di Indonesia, jumlah penderita DM menempati peringkat 4 terbesar di dunia pada tahun 2016 yaitu 8.4 juta jiwa dan akan terus meningkat menjadi 21.2 juta jiwa pada tahun 2030 (WHO, 2016)

DM merupakan penyakit yang berkaitan dengan gangguan metabolisme glukosa darah yang diakibatkan oleh adanya kerusakan sel $\beta$-pankreas (DM tipe 1) dan multiple metabolic abnormalities berupa gangguan sekresi insulin, resistensi insulin, hilangnya fungsi sel $\beta$-pankreas, gangguan regulasi sekresi glukagon dan gangguan fisiologi incretin (DM tipe 2) (Powers, 2008; Andukuri et al., 2009).

Saat ini, pengobatan baru DM telah dikembangkan melalui sistem increatin. Meskipun

\footnotetext{
• email korespondensi: martina.kurniarohmah@gmail.com
} 
dengan efektivitas yang moderat, pengobatan pada jalur ini tidak menimbulkan efek samping sistemik. Incretin adalah hormon gastrointestinal yang dilepaskan setelah kita makan serta menyebabkan augmentasi dan sekresi insulin. Ada 2 jenis incretin yaitu Glucose-Dependent Insulinotropic Peptide (GIP) dan Glukagon Like Peptide-1 (GLP-1). Kedua hormon ini dapat menginduksi sebanyak $60 \%$ sekresi insulin. Selain itu GLP-1 memiliki beberapa fungsi penting diantaranya penurunan sekresi glukagon, meningkatkan integritas sel $\beta$ pankreas, memperlambat pengosongan lambung, menurunkan sekresi asam, meningkatkan buangan glukosa, meningkatkan sintesis glikogen, meningkatkan lipogenesis, serta menyebabkan rasa kenyang sehingga mengurangi makanan yang masuk (Campbell et al., 2010). Sayangnya, GLP-1 memiliki waktu paruh yang sebentar yaitu hanya 12 menit dan didegradasi melalui metabolisme oleh enzim dipeptydil peptidase IV (DPP-4) dan endopeptidase (NEP) (Meier et al., 2004).

Salah satu bentuk pathogenesis dari DM yaitu terjadinya peningkatan aktivitas enzim DPP4 dan reduksi efek incretin yang menyebabkan ketidaknormalan sejumlah metabolisme glukosa di dalam tubuh. Sejumlah obat DM dirancang melalui mekanisme jalur untuk menghambat DPP-4 agar sinyal pada sekresi insulin dapat ditingkatkan dan metabolisme glukosa kembali normal. Penelitian ini bertujuan untuk mengetahui potensi senyawa Alliin pada bawang putih (Allium sativum) sebagai inhibitor DPP-4 secara in silico menggunkan molekular docking.

\section{METODE PENELITIAN}

Preparasi Ligand dan Reseptor. Preparasi ligand dilakukan dengan mendapatkan data ligand reseptor pada PDB (Protein Data Base). Ligand yang digunakan yaitu S- Allyl Cystein sebagai salah satu senyawa di dalam bawang putih. Ligand yang digunakan yaitu Alliin (PDB: 2HOR). Reseptor yang digunakan adalah DPP-4 (PDB: 3CCB). Adapun kontrol yang digunakan adalah Saxagliptin (PDB: 3W2T) yang dapat menurunkan ekspresi DPP-4 dengan 10 kali lipat lebih besar dibandingkan dengan sitagliptin dan vildagliptin meskipun secara klinis efek ketiganya hampir sama (Kulasa dan Edelman, 2010). Berikut ini merupakan gambar struktur molekular dari senyawa

Molekular Docking. Docking merupakan salah satu studi in silico untuk mengetahui interaksi antara protein dengan protein dan dalam hal ini adalah ligand dengan reseptor. Proses docking yang dilakukan pada studi ini menggunakan web server bernama docking server. Untuk melakukan docking pada docking server, langkah pertama yaitu memasukkan (input) data protein pada "my protein" (sebagai reseptor) dan ligand pada "my ligand" menggunakan satu dari dua cara yaitu upload file PDB dari protein yang sudah kita miliki atau dengan mengakses RCSB yang sudah terkoneksi dari docking server. Setelah proses ini berhasil (done) maka proses docking dapat dilakukan. Hasil (output) dari proses docking menggunakan docking server adalah berupa geometry hasil docking, data mengenai energi untuk berikatan, interaksi antar kompleks ligandreseptor, dan parameter

\section{HASIL}

Adanya interaksi antara ligand Alliin pada reseptor target DPP-4 terlihat berdasarkan hasil docking molekular yang ditunjukkan oleh luas permukaan yang berinteraksi (interact surface), jumlah energi ikatan bebas (Est. Free Energy of Binding), dan nilai konstanta inhibisi (Est. inhibition constant). Berikut ini merupakan hasil docking molekular antara senyawa Alliin dengan DPP-4 dibandingkan dengan kontrol yaitu Saxagliptin dan senyawa Allicin yang juga terkandung di dalam bawang putih.

Tabel 1 Hasil Perbandingan Luas Interaksi Permukaan Molekul, Jumlah Energi Ikatan Bebas dan Nilai Konstanta Inhibisi (Ki) pada Interaksi Alliin sebagai berikut:

\begin{tabular}{|llcc|}
\multicolumn{1}{|c}{$\begin{array}{c}\text { Kompleks } \\
\text { Molekul }\end{array}$} & $\begin{array}{c}\text { Interact. } \\
\text { Surface }\end{array}$ & $\begin{array}{c}\text { Est. Free } \\
\text { Energy of } \\
\text { Binding }\end{array}$ & $\begin{array}{c}\text { Est.Inhibition } \\
\text { Constant (Ki) }\end{array}$ \\
\hline $\begin{array}{l}\text { Saxagliptin- } \\
\text { DDP-4 }\end{array}$ & 110.371 & $-0.67 \mathrm{kcal} / \mathrm{mol}$ & $808.93 \mathrm{mM}$ \\
\hline Alliin - DPP-4 & 120.032 & $-0.59 \mathrm{kcal} / \mathrm{mol}$ & $792.92 \mathrm{mM}$ \\
\hline Allicin - DPP-4 & 133.77 & $-0.50 \mathrm{kcal} / \mathrm{mol}$ & - \\
\hline
\end{tabular}


Adapun gambar 3D kompleks Alliin, Saxagliptin, dan Allicin dengan DPP-4 adalah sebagai berikut:

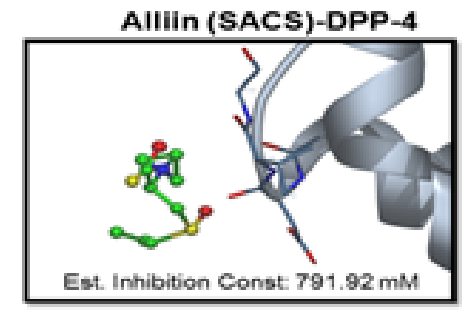

Saxagliptin-DPP-4
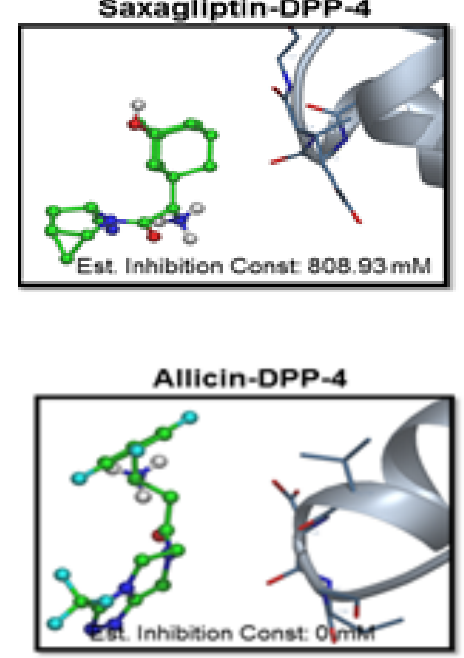

Gambar 1 Gambar 3D Kompleks Molekul Senyawa Alliin-DPP4, SaxagliptinDPP-4, dan Allicin-DPP-4.

Berdasarkan hasil docking diketahui bahwa Alliin dapat berikatan kuat dengan DPP-4 dibuktikan dengan tingginya nilai interaction surface dibandingkan dengan kontrol Saxagliptin yaitu 120.032 dibanding 110.371. Kestabilan ikatan molekul Alliin dan DPP-4 didukung oleh kecilnya nilai ikatan bebas yang mengindikasikan kecilnya energi yang dibutuhkan untuk berikatan. Jika kompleks ikatan memiliki nilai energi ikatan bebas yang kecil (semakin negatif), maka ketika kompleks tersebut terpisah untuk dapat melekat kembali tidak membutuhkan energi yang besar. Nilai energi ikatan bebas kompleks Alliin-DPP-4 adalah - $0.59 \mathrm{kcal} / \mathrm{mol}$ hampir senilai dengan saxagliptin-DPP-4 yaitu $-0.67 \mathrm{kcal} / \mathrm{mol}$.

Selain kemampuan berikatan kuat dan kestabilan ikatan, kemampuan untuk menghambat aktivitas reseptor target sangatlah penting dalam penelitian ini. Kemampuan penghambatan (inhibisi) tersebut ditunjukkan dengan nilai konstanta inhibisi yang kecil yaitu $792.92 \mathrm{mM}$ lebih kecil dari Saxagliptin yaitu $808.93 \mathrm{mM}$. Semakin rendah nilai konstanta inhibisi (Ki) berarti makan semakin efektif aktivitas penghambatannya sebab konsentrasi molekul yang dibutuhkan untuk dapat menghambat DPP-4 semakin kecil.

\section{PEMBAHASAN}

Bawang putih (Allium sativum) terutama bagian umbinya diketahui memiliki aktivitas antidiabetes di antaranya meningkatkan sekresi insulin dan menurunkan level glukosa plasma (Mustafa et l., 2007), memiliki aktivitas insulinotropik dibandingkan dengan hypoglikemik (Islam et al., 2008), menurunkan level glikasi albumin pada darah sebanyak 79,1\% (Sheikh et al., 2004), memperbaiki sensitivitas insulin pada tikus dalam 8 minggu (Padiya et al., 2011), serta tidak memiliki resiko kardiovaskular (Banerjee dan Maulik, 2002). Ada dua senyawa utama di dalam bawang putih yang banyak diketahui memiliki aktivitas antidiabetes yaitu alliin ( $\mathrm{S}$-allyl cystein sulphoxide) dan allicin (diallyl disulphide-oxide). Keduanya sama-sama memiliki aktivitas dalam meningkatkan sekresi insulin, namun belum diketahui apakah keduanya merupakan inhibitor DPP-4.

Saxagliptin merupakan obat inhibitor DPP-4 pada diabetes mellitus dan terbukti memiliki beberapa aktivitas di antaranya menurunkan hemoglobin terikat glukosa $\left(\mathrm{HbA}_{\mathrm{Ic}}\right)$ dan glukosa plasma puasa, memperbaiki fungsi sel $\beta$-pankreas, meningkatkan postprandial insulin, menurunkan postprandial glukagon, dengan resiko hypoglikemia dan penyakit kardiovaskular yang rendah. Saxagliptin memiliki kemampuan berikatan dengan sisi aktif dan kemampuan menghambat DPP-4 10 kali lipat lebih besar dibandingkan dengan sitagliptin dan vildagliptin meskipun secara klinis efek ketiganya hampir sama (Kulasa dan Edelman, 2010).

Berangkat dari persamaan struktur antara alliin dengan beberapa obat inhibitor DPP-4 seperti saxagliptin, sitagliptin dan vildagliptin, maka diduga bahwa alliin berpotensi sebagai inhibitor DPP-4. Berikut ini merupakan kesamaan struktur tersebut (Noor et al., 2013):

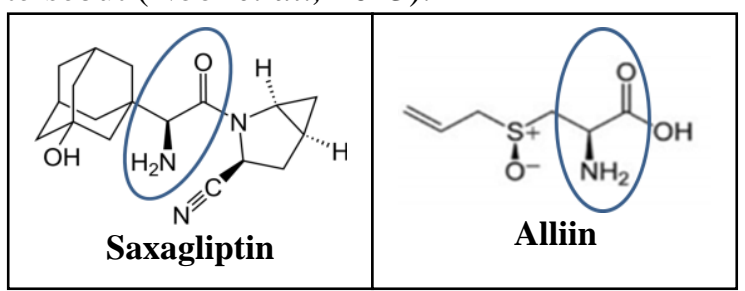

Gambar 1 Persamaan Struktur Allin dengan Saxagliptin dan Sitagliptin 
Ikatan rangkap $\mathrm{O}(=\mathrm{O})$ akan berikatan dengan sisi glutamic dari GLP-1 dan $\mathrm{NH}_{2}$ akan berikatan dengan sisi aktif tyrosine kinase dari GLP-1 sehingga kombinasi keduanya mencegah pengikatan DPP-4 dengan GLP-1 dan memberi hambatan pada DPP-4. Sedangkan allicin tidak memiliki struktur ikatan rangkap $\mathrm{O}(=\mathrm{O})$ dan $\mathrm{NH}_{2}$, sehingga kemungkinan alliin lebih berpotensi sebagai DPP4 inhibitor dibandingkan allicin.

Sejauh ini belum ada penelitian yang mengkaji apakah alliin dan allicin memiliki aktivitas penghambatan pada DPP-4, maka sebagai langkah awal membuktikan hipotesis ini maka dilakukan suatu uji in silico yaitu berupa docking untuk mengetahui apakah ada daya hambat alliin maupun allicin pada DPP-4 dan seberapa besar energi yang dibutuhkan senyawa tersebut untuk berikatan. Untuk itu digunakan saxagliptin sebagai kontrol atau pembanding karena saxagliptin memiliki daya hambat yang paling baik terhadap DPP-4 dibandingkan dengan sitagliptin maupun vildagliptin.

Hasil uji in silico ini membuktikan dugaan bahwa dengan kesamaan struktur ikatan rangkap $\mathrm{O}$ $(=\mathrm{O})$ dan $\mathrm{NH}_{2}$ antara alliin dengan saxagliptin dan sejumlah inhibitor DPP-4 lainnya membuat senyawa ini berpotensi untuk menghambat DPP-4. Secara struktural, struktur ini mampu berikatan dengan GLP-1, namun dengan studi in silico struktur ini terbukti dapat memberikan efek penghambatan pada DPP-4. Sehingga dapat dibuktikan bahwa alliin memiliki kemampuan pengikatan dengan GLP-1 sekaligus pengikatan dengan DPP-4 dan menghambat aktivitasnya. Meskipun demikian, penelitian dalam skala laboratorium sangat dibutuhkan untuk mengetahui secara pasti efek hambatan alliin terhadap DPP-4 dan efeknya bagi sejumlah metabolisme yang berkaitan dengan diabetes mellitus difasilitasi oleh adanya perbaikan fungsi dari incretin.

Berdasarkan Standard Medical Care in Diabetes dari The American Diabetes Association (2015), Obat inhibitor DPP-4 merupakan salah satu obat DM dengan resiko yang rendah dan tidak laporan mengenai efek samping yang ditimbulkan meskipun efektivitasnya termasuk intermediet berdasarkan penurunan A1C dibandingkan dengan obat lain seperti insulin dan biguanide. Inhibitor DPP-4 merupakan jalur pengobatan yang tergolong baru pada DM. Inhibitor DPP-4 bekerja pada sistem incretin yang mencegah aktivitas DPP-4 dalam mendegradasi GLP-1 dan GIP yang berperan dalam menstimulasi sekresi insulin. Inhibitor DPP-4 juga dapat menurunkan sekresi glukagon, melambatkan pengosongan lambung, dan meningkatkan lama waktu kenyang.

\section{KESIMPULAN}

Pengobatan DM melalui jalur sistem incretin dan DPP-4 inhibitor merupakan pengobatan yang efektif dan tidak menimbulkan efek samping sistemik. Secara in silico, senyawa Alliin dalam bawang putih (Allium sativum) memiliki kemampuan berikatan kuat, stabil, dan penghambatan yang lebih baik dibandingkan dengan obat inhibitor DPP-4 yang sudah ada seperti Saxagliptin. Meskipun telah terbukti dapat berikatan kuat, stabil, dan terjaga dengan reseptor DPP-4 secara in silico, maka penelitian dry lab ini perlu dilanjutkan dengan penelitian wet lab untuk membuktikan aktivitas senyawa alliin dalam menghambat DPP-4 atau sebagai DPP-4 inhibitor.

\section{DAFTAR PUSTAKA}

Andukuri, R., Drincic, A., dan Rendell, M. 2009. Alogliptin : A New Addition to the Class of DPP-4 Inhibitors. Diabetes, Metabolic syndrome and Obesity: Targets and Therapy. 2: 117-126.

The American Diabetes Association. 2015. Standards of Medical Care in Diabetes. The Journal of Clinical and Applied Research and Education. 38(1): 1-94.

Banerjee, S. K dan Maulik, S. K. 2002. Effect of Garlic on Cardiovascular Disorders: A Review. Nutrition Journal. 1: 1-14.

Campbell, R. K., Cobble, M. E., Reid, T. S, dan Shomali, M. E. 2010. Distinguishing Among Incretin-Based Therapies. Pathophysiology of Type 2 Diabetes Mellitus: Potential Role of Incretin-Based Therapies. J. Fram. Pract. 59(9): 5-9.

Islam, M. S dan Choi, H. 2008. Dietary Red Chilli (Capsicum frutescens L.) is Insulinotropic Rather than Hypoglycemic in Type 2 Diabetes Model of Rats. Phytother Res. 22(8): 1025-1029.

Kulasa, Kristen dan Edelman, Steven. 2010. Saxagliptin: the Evidence for Its Place in the Tretment of Type 2 Diabetes Mellitus. Dove Medical Press.DOI: 10.2147/CE.S8006.

Noor, A., Bansal, V. S., dan Vijayalaksmi, M, A. 2013. Current Update on Anti-Diabetic Biololecules from Key Traditional Indian 
Medicinal Plants, Review Article. Curretn Science. 104 (6): 1-7.

Meier, J. J., Nauck, M. A., Kranz, D., Holst, J. J., Deacon, C. F., dan Gaeckler, D. et al. 2004. Secretion, Degradation and Elimination of Glucagon-Like Peptide 1 and Gastric Inhibitory Polypeptide in Patients with Chronic Renal Insufficiency and Healthy Control Subjects. Diabetes, 53 (3): 654662.

Mustafa, S. S. S., Eid, N. I., Jafri, S. A., El-Latif, H. A. A., Ahmed, H. M. S. 2007. Insulinotropic Effect of Aqueous Ginger Extract and Aqueous Garlic Extract on the Isolated Perfused Pancreas of Streptozotocin Induced Diabetic Rats. Pak J Zool. 39 (5): 279-284.

Padya, R., Khatua, Tarak. N., Bagul, Pankaj, K., Kuncha, M., dan Banerjee, S. K. 2011.
Garlic Improves Insulin Sensitivity and Associated Metabolis Syndromes in Fructose Fed Rats. Nutrition \& Metabolism . 8 (53): 1-8.

Powers, A. C., dan D', A. David. 2011. Endocrine Pancreas and Pharmacotherapy of Diabetes Mellitus and Hypoglycemia. Goodman \& Gilman's The Pharmacological Basis of Therapeutics, 12th ed., Mcgraw-Hill, New York, pp.1237-1273.

Sheikh, N., Safari, M. R., Kashani, Mani., Araghchian, M., Seraati, F. 2004. Study on the Effect of Garlic on the in vitro Albumin Glycation Reaction. Acta Medica Iranica. 42 (1): 1-3.

World Health Organization (WHO). 2016. Global Report on Diabetes. ISBN 978924 156525 7. www.who.int. 